\title{
Assembly and Function of Gonad-Specific Non-Membranous Organelles in Drosophila piRNA Biogenesis
}

\author{
Shigeki Hirakata and Mikiko C. Siomi * \\ Department of Biological Sciences, Graduate School of Science, The University of Tokyo, Tokyo 113-0032, Japan; \\ hirakata@bs.s.u-tokyo.ac.jp \\ * Correspondence: siomim@bs.s.u-tokyo.ac.jp; Tel.: +81-3-5841-4386
}

Received: 27 September 2019; Accepted: 4 November 2019; Published: 6 November 2019

\begin{abstract}
PIWI-interacting RNAs (piRNAs) are small non-coding RNAs that repress transposons in animal germlines. This protects the genome from the invasive DNA elements. piRNA pathway failures lead to DNA damage, gonadal development defects, and infertility. Thus, the piRNA pathway is indispensable for the continuation of animal life. piRNA-mediated transposon silencing occurs in both the nucleus and cytoplasm while piRNA biogenesis is a solely cytoplasmic event. piRNA production requires a number of proteins, the majority of which localize to non-membranous organelles that specifically appear in the gonads. Other piRNA factors are localized on outer mitochondrial membranes. In situ RNA hybridization experiments show that piRNA precursors are compartmentalized into other non-membranous organelles. In this review, we summarize recent findings about the function of these organelles in the Drosophila piRNA pathway by focusing on their assembly and function.
\end{abstract}

Keywords: PIWI; piRNA; transposon; Yb body; Flam body; Dot COM; nuage; mitochondrion; Drosophila; ovary

\section{Introduction}

piRNAs are 24-35-nucleotide (nt) long non-coding RNAs that specifically associate with members of the PIWI subclade of the Argonaute protein family in a stoichiometric manner [1-7]. The association between PIWI and piRNA produces the piRNA-induced silencing complex (piRISC), the core engine of piRNA-mediated transposon silencing.

piRNAs have been identified in a variety of animals, ranging from hydra, sea anemone, flies, fish, and mammals, including humans [8,9]. In these species, piRNAs are produced from long non-coding RNAs transcribed from piRNA clusters. piRNA clusters are intergenic elements rich in transposon remnants dedicated for piRNA production via complicated biogenesis machineries. piRNAs mostly have sequences that are antisense to those of transposon mRNAs. Therefore, piRNAs can target piRISCs to transposon mRNAs to induce transposon repression. While some transposons in animals belong to the same family (e.g., long terminal repeat-type) [10], their sequences are not always conserved across species [11]. Therefore, the sequences of piRNA clusters and piRNAs are not conserved in sequences among species.

The number of PIWI members also differ in different species. For instance, Drosophila has three PIWI members, Piwi, Aubergine (Aub), and Ago3, while humans have four PIWI members, PIWIL1 to PIWIL4. Even in one species, the piRNAs loaded onto individual PIWI members show unique traits. In Drosophila, piRNAs loaded onto Piwi and Aub are mostly antisense to transposon mRNAs, while Ago3-bound piRNAs show a bias for the sense strand. Piwi- and Aub-bound piRNAs preferably 
contain uracil at the $5^{\prime}$ end, while Ago3-bound piRNAs tend to have adenine at the 10th nucleotide from the $5^{\prime}$ end [12,13]. The length of piRNAs associated with each PIWI member also vary. Piwi-piRNAs are about $26 \mathrm{nt}$ long while Aub- and Ago3-piRNAs are about $25 \mathrm{nt}$ and $24 \mathrm{nt}$, respectively [12].

The sequences of Piwi- and Aub-bound piRNAs are often identical. However, upon piRNA loading Aub and Piwi are localized to the cytoplasm and nucleus, respectively [12,14,15]. How they repress transposons also differ, with Piwi silencing transposons transcriptionally and Aub (and Ago3) doing so post-transcriptionally [1-7]. Lack of either of Piwi or Aub causes infertility, indicating that other family members do not compensate for their loss-of-function [16-20].

As members of the AGO subfamily of Argonaute proteins, cytoplasmic PIWI members, such as Drosophila Aub and Ago3, possess Slicer endonuclease activity and implement transposon silencing post-transcriptionally. In contrast, nuclear PIWI members, such as Drosophila Piwi, silence transposons transcriptionally in collaboration with multiple co-factors by inducing DNA methylation, repressive histone modification, and heterochromatinization [1-7]. Drosophila has both nuclear and cytoplasmic PIWI members, and subsequently has both transcriptional and post-transcriptional transposon silencing. In contrast, only cytoplasmic PIWI members are expressed in silkworm, and they do not possess transcriptional transposon silencing mechanisms [21]. Species-specific sex differences in PIWI member expression have also been reported. Mice express three PIWI members, all of which are essential for male, but not of female, fertility [22-24]. Drosophila requires all PIWI members for both female and male gonadal development and fertility [16-20].

piRNA studies have been extensively performed in flies, nematodes, and mice [3-5,8]. Biochemical and bioinformatic progress have recently been made in Drosophila cultured cell systems consisting of ovary-originating cells, such as fGS/OSSs and OSCs $[25,26]$. Both of these systems have functioning piRNA pathways, and interference in these pathways de-silences transposons. In this review, we outline the current understanding of the piRNA pathway in Drosophila, and share recent findings on gonad-specific non-membranous organelles and mitochondria, all of which contribute to piRNA biogenesis in Drosophila.

\section{The piRNA Pathway in Drosophila Ovaries: The Outline}

The Drosophila ovaries consist of germ (oocytes and nurse) cells and somatic (follicular) cells that surround the germ cells and produce eggshells [27,28]. The germ (nurse) cells express all PIWI members-Ago3, Aub, and Piwi-while ovarian somatic cells only express Piwi (Figure 1a) [12,14,29]. Aub and Ago3 are cytoplasmic and repress transposons post-transcriptionally [12,13]. Piwi is localized in the nucleus and represses transposons transcriptionally with co-factors, including Panoramix (Panx), Gtsf1, Nxf2, Nxt1/p15, Maelstrom (Mael), Eggless (Egg), histone linker H1, and HP1 [2,7,12,14,15,30-47].

In Drosophila, piRNA clusters are classified as either uni-strand or dual-strand depending on the directionality of transcription (Figure 1a) $[2-4,7,8,12,48,49]$. Uni-strand clusters are literally transcribed in one fixed direction while dual-strand clusters are transcribed in both directions. Ovarian somatic cells dominantly use uni-strand clusters, the representative of which is flamenco/COM (flam) $[2-4,7,8,12,48,49]$. In contrast, germ cells dominantly use dual-strand clusters for piRNA expression [2-4,7,8,12,48,49]. The most commonly expressed piRNA cluster in germ cells is $42 A B$. The uni-strand clusters are transcribed by RNA polymerase II (Pol II) as regular protein-coding genes are and the RNA transcripts are exported to the cytoplasm by the system that regular mRNAs depend for their export (for details, see Section 3). In contrast, the dual-strand clusters require a quite unique system for their transcription, involving germ-specific factors such as Rhino, Deadlock, Cutoff, and Moonshiner [50-55]. The resultant RNA transcripts are then exported to the cytoplasm in an Nxf3- and Bootlegger-dependent manner [56,57].

A subset of protein coding-genes also give rise to piRNAs in addition to proteins. piRNAs are particularly produced from the $3^{\prime}$ untranslated region ( $3^{\prime}$ UTR) and are known as "genic piRNAs" [25,58]. The most studied of these is the traffic jam ( $t j)$ gene in ovarian somatic cells. Genic piRNAs, in general, are unrelated to transposon silencing. The bona fide targets of genic piRNAs remain elusive. 


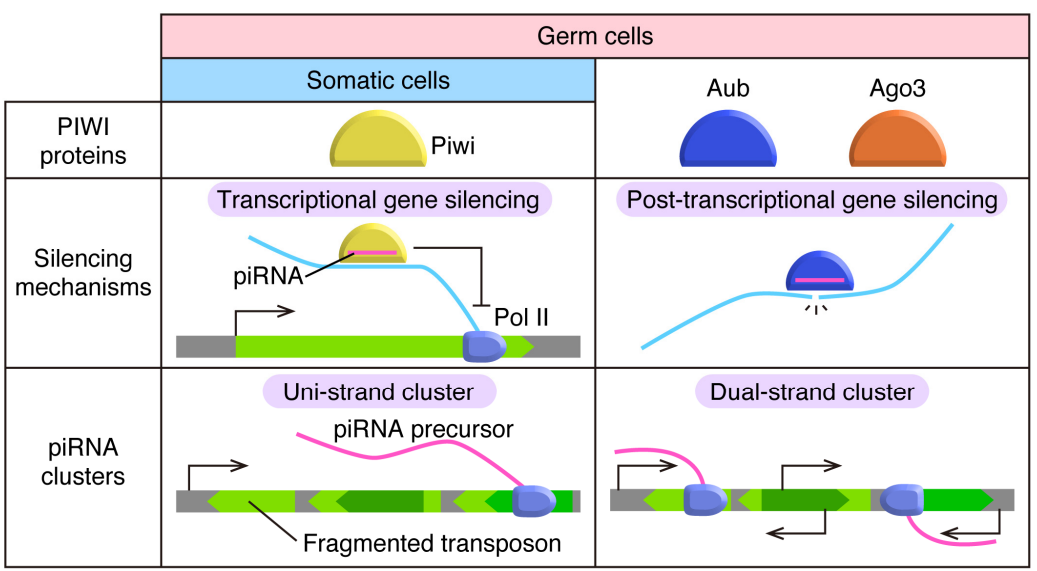

(a)

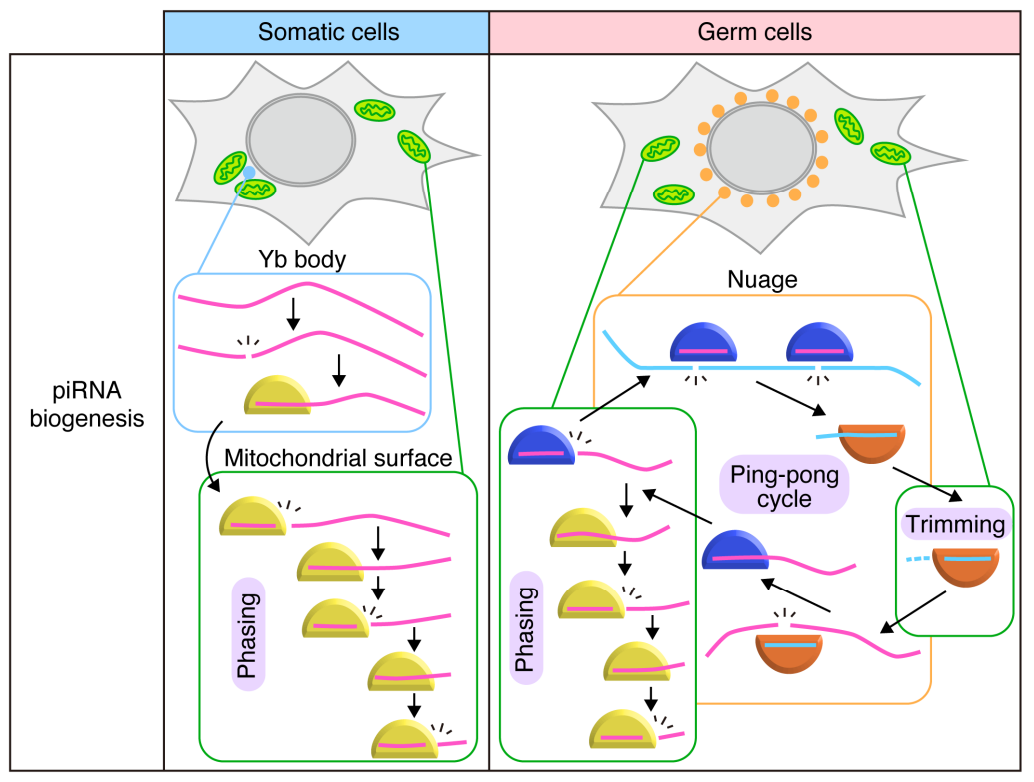

(b)

Figure 1. Comparison of Drosophila ovarian piRNA pathways in somatic cells and germ cells. (a) Comparison of PIWI proteins, silencing mechanisms, and piRNA clusters. Sole PIWI protein expressed in somatic cells, Piwi, is imported to nuclei once loaded with piRNA and represses transposon co-transcriptionally. In somatic cells, piRNA precursors are transcribed from uni-strand clusters, which are transcribed uni-directionally and produce transcripts harboring fragments of transposons in reverse orientation. In germ cells, Aub and Ago3 are expressed in addition to Piwi. Aub and Ago3 stay in the cytoplasm and cleave target transcripts using Slicer activities. piRNAs in germ cells are derived from both uni-strand and dual-strand clusters. Dual-strand clusters are transcribed from both strands of DNA, and transposon fragments are inserted in random orientations. (b) Comparison of piRNA biogenesis pathways. In somatic cells, dominant piRNA precursors, flamenco/COM (flam) transcripts, are selected and initially cleaved in $\mathrm{Yb}$ bodies, soma-specific perinuclear granules surrounded by mitochondria. Continuous cleavages of intermediate RNA on the outer membrane of mitochondria produce mature 'phased' piRNAs. In germ cells, reciprocal cleavage of target transcripts by Aub and Ago3 produce Ago3-bound and Aub-bound piRNAs, respectively. This cycle is called the ping-pong cycle. Through the ping-pong cycle, transposon transcripts (light blue) are cleaved and piRNAs are amplified. Cleavage of targets and loading of cleaved fragments onto PIWI proteins during the cycle occurs in germ-specific perinuclear granules called nuage. Maturation of Ago3-loaded piRNAs through trimming presumably occurs on the outer membrane of mitochondria. Loading of antisense RNA (magenta) on Aub triggers phased piRNA biogenesis on the mitochondrial outer membrane. 
Transcription of the piRNA clusters takes place in the nucleus, but processing of cluster transcripts occurs in the cytoplasm and requires numerous factors (Figure 1b). Some factors participate in piRNA biogenesis in both germ and somatic cells, but others are cell type-specific [2-5,7,8,59]. In ovarian somatic cells, piRNA processing factors are localized to either perinuclear non-membranous granules, $\mathrm{Yb}$ bodies, or outer mitochondrial membranes. Female sterile (1) $\mathrm{Yb}(\mathrm{Yb})$, Armitage (Armi), Sister of $\mathrm{Yb}(\mathrm{SoYb})$, Vreteno (Vret), and Shutdown (Shu) are detected at $\mathrm{Yb}$ bodies, while Zucchini (Zuc), Gasz, Minotaur (Mino), and Daedalus (Daed) are detected on mitochondria (for details, see Sections 4 and 5) [60-68]. Armi, Vret, and Zuc are also expressed in germ cells [48,63,67-76]. Germ-specific factors include Brother of $\mathrm{Yb}$ (BoYb), Spindle-E/Homeless (Spn-E), and Qin/Kumo (Qin) [64,77-79].

$\mathrm{Yb}$ bodies are not assembled in germ cells [60]. This is simply because the core factor of $\mathrm{Yb}$ body assembly, $\mathrm{Yb}$, is not expressed in the cells. Germ cells form a similar type of non-membranous granules called the nuage (Section 6) [80,81]. Using RNA in situ hybridization, dotty structures called Dot COM/Flam bodies were visualized in ovarian somatic cells, where the flam RNA transcripts (i.e., flam-piRNA precursors) accumulate (Section 3) [82-86].

Upon piRISC assembly, Aub cleaves transposon mRNAs, which then serve as substrates for producing piRNAs for Ago3 (Figure 1b). Therefore, Ago3-loaded piRNAs are mostly parallel, or in sense orientation, to transposon mRNAs. Ago3 then cleaves transposon transcripts in the antisense orientation. piRNAs produced from this reaction assemble piRISCs with Aub [12,13]. This reciprocal cleavage by Aub and Ago3 in sense and antisense directions, respectively, keeps producing Ago3and Aub-bound piRNAs [12,13]. At the same time, transposons are repressed post-transcriptionally. This system, widely known as the "ping-pong cycle", is considered to be the coupled event of transposon repression and piRNA biogenesis [12,13]. The ping-pong cycle is germ cell-specific and occurs in the nuage in the cells (Section 6).

\section{Flam Body/Dot COM: Dotty Structures Where piRNA Precursors Accumulate before Processing in Ovarian Somatic Cells}

The flam piRNA cluster is the origin of transposon-targeting piRNAs in OSCs $[12,20,25,48,87]$. flam transcription represses a number of transposons [48,88-90]. However, the flam piRNA cluster is inactive in germ cells, suggesting that piRNA-dependent transposon silencing is distinct in somatic and germ cells. The flam locus has a single promoter and transcription is induced by the Cubitus interruptus transcription factor $[31,91]$. The resultant transcripts are $5^{\prime}$-capped, polyadenylated, and alternatively spliced [91], hallmarks of canonical Pol II-dependent RNA products.

RNA fluorescent in situ hybridization (FISH) experiments show that flam RNAs accumulate at Dot COM [82-85]. Dot COM is found in both the nucleus and the cytoplasm (Figure 2). In the nucleus of wild-type ovaries, Dot COM is detected far from the flam locus. However, upon knockdown of components of the exon junction complex (EJC) and/or UAP56, known mRNA nuclear export factors, Dot COM is located proximal to the flam locus. This indicates that Dot COM might be assembled at the flam transcription site and move across the nuclei in an EJC- and UAP56-dependent manner [83]. The transcripts of other piRNA cluster components are also detected at Dot COM [82]. The mechanism of and/or requirement for Dot COM assembly remains elusive. 


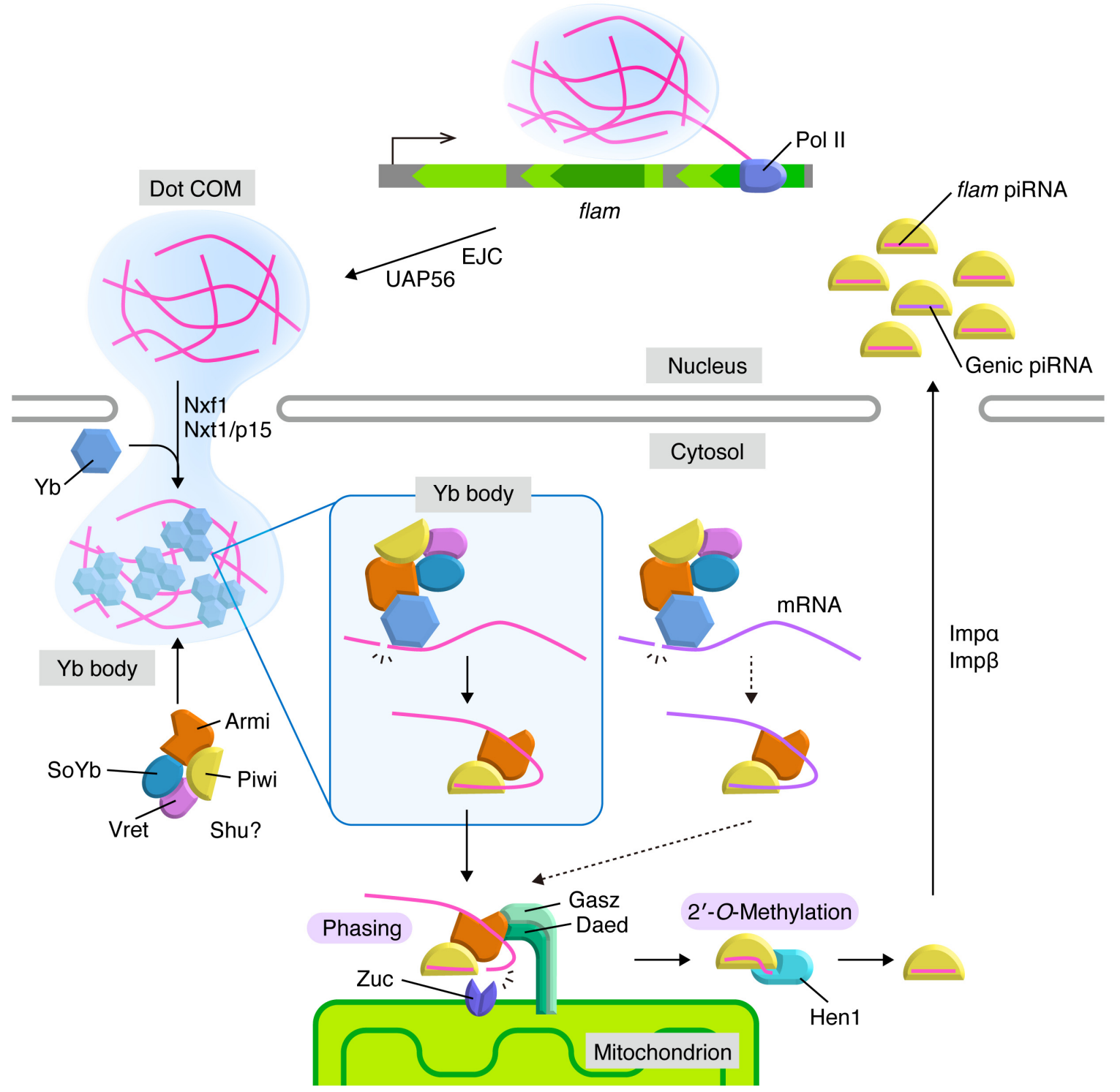

Figure 2. piRNA biogenesis pathway in Drosophila ovarian somatic cells. Transcripts of flam (magenta) generate Dot COM in the nucleus and are translocated to nuclear periphery in a manner dependent on Exon Junction Complex (EJC) and UAP56. Dot COM is exported to the cytoplasm by the Nxf1-Nxt1/p15 complex. In the cytoplasm, flam transcripts are processed into piRNA intermediates in $\mathrm{Yb}$ bodies. $\mathrm{Yb}$ and flam require each other for granularization in the cytoplasm. The Armi-Piwi-piRNA intermediate complex moves to the surface of the mitochondrial outer membrane, where phased piRNAs are produced in mature lengths by endoribonuclease Zuc. After Hen1-mediated 2'-O-methylations at the piRNA $3^{\prime}$ ends, piRISCs are imported into the nucleus, where they co-transcriptionally repress their targets. Some mRNAs (violet) are also processed into piRNA intermediates in the cytosol at low efficiency and generate genic piRNAs through phasing on mitochondria. The targets and functions of genic piRNAs are vague.

The export of flam transcripts depends on two mRNA export factors: Nxt1/p15 and Nxf1 [83]. Dot COM was detected to move across the nuclear pores to localize to the cytoplasm [83,84]. RNA FISH experiments determined that the flam RNAs accumulate in cytoplasmic structures called Flam bodies. Flam bodies are detected adjacent to $\mathrm{Yb}$ bodies and their formation is $\mathrm{Yb}$-dependent [86]. It is highly likely that Flam bodies and cytoplasmic Dot COM are identical, but this has not yet been proven experimentally. $\mathrm{Yb}$ is a cytoplasmic protein, so formation of nuclear Dot $\mathrm{COM}$ may be $\mathrm{Yb}$-independent. 


\section{Yb Bodies: Cytoplasmic Non-Membranous Organelles Where Transposon-Targeting piRNA Precursors Undergo Primary Processing in Ovarian Somatic Cells}

$\mathrm{Yb}$ bodies are ovarian soma-specific, cytoplasmic non-membranous organelles. $\mathrm{Yb}$ bodies are located at perinuclear regions and there are only a few $\mathrm{Yb}$ bodies per cell [86]. $\mathrm{Yb}$, Armi, SoYb, Vret, and Shu are components of $\mathrm{Yb}$ bodies (Figure 2) [60-65]. Knockdown of $\mathrm{Yb}$, but not of the other components, causes the disappearance of $\mathrm{Yb}$ bodies. Therefore, $\mathrm{Yb}$ is considered the core component of $\mathrm{Yb}$ body assembly. The hierarchy of the other components in $\mathrm{Yb}$ body assembly is Armi to the SoYb-Vret heterodimer [61-65,92]. SoYb and Vret interact with and stabilize each other in vivo [92].

$\mathrm{Yb}$ has Helicase-C terminal (Hel-C), DEAD-box RNA helicase, and extended Tudor (eTud) domains $[60,64,92]$. The latter two domains confer RNA-binding activity to $\mathrm{Yb}$, while the N-terminal $\mathrm{Hel}-\mathrm{C}$ domain acts as a $\mathrm{Yb}$ self-assembly domain. The $\mathrm{C}$-terminal eTud domain also plays a role in $\mathrm{Yb}$-Armi binding [92]. Yb fails to interact with the SoYb-Vret heterodimer in the absence of Armi [92]. The eTud domain is also proposed to interact with the SoYb-Vret heterodimer through Armi.

$\mathrm{Yb}$ bodies are not formed if $\mathrm{Yb}$ is present in the cells but lacks RNA-binding activity [86]. This is consistent with the observation that the flam mutant ovaries form almost no $\mathrm{Yb}$ bodies [83,84]. Taken together, these results indicate that $\mathrm{Yb}$ binding to piRNA precursors, other than flam, is insufficient for $\mathrm{Yb}$ body assembly. Likewise, $\mathrm{Yb}$ mutants lacking self-association activity fail to assemble $\mathrm{Yb}$ bodies, even when the RNA-binding activity is maintained [92]. flam RNAs contain numerous Yb-binding sites, while genic piRNA sources have only a few 3' UTR-restricted Yb-binding sites [93]. Based on these observations, it was inferred that $\mathrm{Yb}$ bodies are multivalent condensates formed by liquid-liquid phase separation (LLPS) requiring both $\mathrm{Yb}$-flam RNAs and $\mathrm{Yb}-\mathrm{Yb}$ associations. Live imaging demonstrated that $\mathrm{Yb}$ bodies in cultured OSCs are dynamic and fuse and divide repetitively, which are hallmarks of LLPS-driven condensates. Like P bodies, $\mathrm{Yb}$ bodies also show sensitivity to the LLPS disruptor, 1,6-hexanediol [92]. Thus, $\mathrm{Yb}$ bodies are LLPS-driven condensates in OSCs.

$\mathrm{Yb}$ bodies used to be known as the place of piRNA biogenesis in OSCs. However, recent studies show that $\mathrm{Yb}$ body formation is not absolutely mandatory for piRNA biogenesis. Indeed, non-transposon-targeting, genic piRNAs are produced in mutant OSCs as efficiently as in normal OSCs. In mutant OSCs ectopically expressing Hel-C lacking $\mathrm{Yb}$ instead of endogenous $\mathrm{Yb}$, the $\mathrm{Yb}$ mutant bound flam RNAs and $t j \mathrm{mRNAs}$ to a similar extent. In contrast, wild-type $\mathrm{Yb}$ bound flam RNAs much more strongly than it did genic piRNA sources, including $t j$ mRNAs [92]. Therefore, a more accurate definition of $\mathrm{Yb}$ bodies reads: $\mathrm{Yb}$ bodies are the place for producing transposon-targeting piRNAs in OSCs.

Armi has intrinsic, promiscuous RNA-binding activity [72,94]. In the presence of $\mathrm{Yb}$, this "randomized" activity is hidden, but in the absence of $\mathrm{Yb}$, Armi blindly induces the production of non-transposon-targeting piRNAs from bound RNAs [94]. Therefore, Armi has the activity to induce piRNA biogenesis in a $\mathrm{Yb}$-independent manner. Indeed, tethering Armi to reporter RNAs in OSCs induces piRNA biogenesis from the reporter $[69,94,95]$. These findings support Armi being the facilitator of piRNA biogenesis in OSCs, with $\mathrm{Yb}$ being the selector of piRNA precursors through cis-elements embedded in the RNAs [93]. When both $\mathrm{Yb}$ and Armi proteins co-exist in vivo, transposon-targeting piRNAs are produced properly and transposons are efficiently silenced. Thus, the piRNA biogenesis pathway in OSCs takes full advantage of the characteristics of both $\mathrm{Yb}$ and Armi. The functions of $\mathrm{SoYb}$, Vret, and Shu in somatic piRNA biogenesis have yet to be fully elucidated.

\section{Mitochondria: Membranous Organelles that Serve as the Place for piRNA Maturation and Phased piRNA Biogenesis}

Zuc, Daed, Mino, and Gasz contain transmembrane signals and localize to the outer membrane of mitochondria in OSCs (Figure 2). Lack of these factors reduces the levels of mature piRNAs and the aberrant accumulation of piRNA intermediates. This indicates that piRNA maturation occurs at the mitochondria $[61,63,66-68]$. Why piRNA factors congregate at the mitochondria to perform the final step in piRNA processing remains unknown. 
Mitochondria surround $\mathrm{Yb}$ bodies in OSCs. This arrangement results in the concentration of piRNA factors and piRNA precursors in the vicinity of mitochondria and facilitates piRNA production $[60,61,86]$. However, there are only a few $\mathrm{Yb}$ bodies per cell and numerous mitochondria [86]. Moreover, there are high levels of piRNAs in OSCs. Therefore, it is very unlikely that only the fraction of Zuc that is located proximal to $\mathrm{Yb}$ bodies functions in piRNA processing. For the proportion of Zuc that is located far from $\mathrm{Yb}$ bodies to function in piRNA processing, RNA substrates would need to travel across the cytosol from $\mathrm{Yb}$ bodies to mitochondria. Recent studies show that the intermediates dynamically move from $\mathrm{Yb}$ bodies to mitochondria in association with Piwi and Armi $[67,96]$. In the complex, Piwi interacts with the $5^{\prime}$-phosphate group of the intermediates [96]. Armi also binds the RNAs but this interaction depends on Piwi [67]. Upon Zuc depletion, Armi aberrantly accumulated on the surface of mitochondria through Gasz. Additional knockdown of Gasz causes Armi to be stuck in $\mathrm{Yb}$ bodies [67,96]. Piwi behaves similarly, but to a lesser extent, and cannot stay longer on Gasz through Armi at the surface of mitochondria when Zuc function is abrogated [96]. The functions of Daed and Mino in OSCs remain elusive.

Armi localizes to $\mathrm{Yb}$ bodies through direct binding with $\mathrm{Yb}$ [92]. This action does not require Piwi [63]. However, Armi remains localized to $\mathrm{Yb}$ bodies in the absence of Piwi, indicating that the departure of Armi from $\mathrm{Yb}$ bodies requires Piwi [96]. Armi has the intrinsic ability to bind RNAs promiscuously. If Armi is released from $\mathrm{Yb}$ bodies, even without piRNA intermediates, Armi would randomly bind RNAs in the cytosol and blindly initiate piRNA production from these bound RNAs. To avoid this unwanted situation, OSCs have evolved a system to ensure that Armi is released from $\mathrm{Yb}$ bodies and is able to head to the mitochondria only upon binding to Piwi-piRNA intermediates.

On mitochondria, Zuc cleaves Piwi-bound piRNA intermediates to excise mature piRNAs. This cleavage determines the $3^{\prime}$ end of the mature piRNA and Piwi-piRISC release $[74,75,97,98]$. The cleavage also generates a novel $5^{\prime}$ end on the intermediate, which is then bound with apo-Piwi (Piwi devoid of piRNAs). In this manner, Zuc continuously and sequentially generates piRNAs, termed phased piRNAs, from one intermediate RNA towards its $3^{\prime}$ end [74,75]. To accomplish this Zuc reaction, the ATP hydrolysis-dependent $5^{\prime}$-to-3' directional RNA helicase activity of Armi is required to relax RNA substrates and Armi has to undergo inter-organelle translocation [69,94]. Sometimes, Zuc produces piRNAs with a few extra bases at the $3^{\prime}$ end. These additional $3^{\prime}$ bases are removed by a $3^{\prime}$-to-5' endonuclease Nibbler (Nbr) in germ cells [99-101]. In contrast, the additional bases are removed by unknown nuclease(s) in a manner dependent on a mitochondrial outer-membrane protein, Papi, in somatic cells [101]. The methyltransferase Hen1/Pimet 2'-O-methylates piRNAs at the $3^{\prime}$ ends to increase their stability in vivo $[100,102,103]$.

In germ cells, SoYb, Zuc, Mino, Gasz, and Daed also localize to the outer mitochondrial membrane where they are involved in piRNA biogenesis $[48,63,66-68,74-76]$. The $3^{\prime}$ end of Aub-loaded piRNAs is determined by Zuc [101]. The remaining $3^{\prime}$ end fragment is funneled into phased piRNA biogenesis, from which Piwi-loaded piRNAs and, to a lesser extent, Aub-bound piRNAs are generated (Figure 1b) $[74,75,101,104,105]$. Translocation of piRNA intermediates from the nuage to mitochondria in germ cells also requires Armi, Gasz, and Daed [67,70,72].

Upon completion of piRNA processing, Piwi-piRISCs are promptly imported to the nucleus in an $\operatorname{Imp} \alpha / \beta$ dependent manner [106]. The nuclear import of Piwi is strictly regulated by Piwi-piRNA association, and apo-Piwi is not imported to the nucleus [61-63,65-68,96,107].

\section{Nuage: The Place for piRNA Amplification and Post-Transcriptional Repression through the Ping-Pong Cycle in Germ Cells}

In germ cells, the vast majority of piRNA factors are found in the nuage. This includes Vasa, Armi, Vret, Shu, BoYb, Krimper (Krimp), Spn-E, and Qin [64,65,67-73,77-79,107]. The hierarchy of these proteins in nuage formation (and/or localization) has primarily been studied genetically, but a solid conclusion has not yet been drawn. More thorough, comprehensive analyses are required to determine 
how the nuage is formed. These factors likely localize to different sets of nuage, and it is possible that the non-membranous structures in germ cells are not uniform [21,108-110].

Vasa is a germline-specific DEAD-box RNA helicase [12,111]. Recent investigations using cultured Bombyx ovary-derived germ cells show that Vasa uses the RNA helicase activity to release cleaved RNAs from Siwi, the silkworm Aub counterpart, upon Slicer-dependent cleavage. These cleaved RNAs are subsequently loaded onto Ago3 (in both fly and silkworm) and processed to mature piRNAs, facilitating the ping-pong cycle [21,112]. Siwi holds cleaved RNAs until Vasa releases them from the protein. This characteristic is unique to PIWI members, and is not observed for AGO members. This is reasonable because RNAs cleaved by AGO are further degraded in the cellular environment to complete target gene silencing, but RNAs cleaved by PIWI serve as the substrate for piRNA biogenesis (Section 2). The Vasa counterpart that works for Ago3 remains undetermined.

The human ortholog of Vasa, Ddx4, can form LLPS-driven condensates [113]. Fly genetic studies show that the nuage is not detected in vasa mutant ovaries $[79,114,115]$. Therefore, it is feasible that in Drosophila the nuage may be constructed through Vasa-driven phase separation.

The unstructured region, but not the helicase domain, of Vasa/Ddx4 is sufficient to induce phase separation [113]. Accordingly, nuage formation is thought to be RNA-independent. However, this notion is still controversial. UAP56, an export factor of piRNA precursors in germ cells, is localized to foci formed on dual-strand piRNA clusters. The nuclear foci are located near the cytoplasmic nuage, across the nuclear membrane [116]. The nuage disappeared in an UAP56 mutant that failed to localize to the cluster foci and did not export piRNA precursors [116]. Thus, nuclear export of piRNA precursors by UAP56 might trigger nuage formation.

Krimp, a Tudor domain-containing protein, plays an important role in the ping-pong cycle $[48,79,117]$. Krimp associates with Ago3 through symmetrically dimethylated arginines on Ago3 and brings it to the nuage, where Ago3 is loaded with piRNAs through the ping-pong cycle $[79,108,118,119]$. In the absence of Krimp, Ago3 becomes devoid of piRNAs and Aub initiates homotypic ping-pong cycles [118]. However, the efficiency of piRNA production through homotypic ping-pong is very low and leads to the eventual derepression of transposons, causing severe damages to the cells. Loss of Qin, another Tudor domain-containing protein, also results in Aub-Aub homotypic ping-pong in the nuage $[77,120]$. Under these conditions, Piwi is loaded with sense transcripts cleaved by Aub [105]. The heterotypic ping-pong cycle ensures that only antisense transcripts are being used for phased piRNA biogenesis and bearing Piwi-loaded piRNAs. OSCs also express Krimp, but it is sequestered in Krimp bodies, cytoplasmic granules that are distinct from $\mathrm{Yb}$ bodies. Interestingly, Krimp is dispensable for piRNA biogenesis in OSCs $[65,118]$. Why Krimp bodies form in OSCs remains unknown.

Studies have also been conducted to understand the functions of the other nuage-specific piRNA factors. However, the results of such studies largely remain vague. Investigations using OSCs and $\mathrm{fGS} / \mathrm{OSS}$ have greatly contributed to our understanding of the mechanisms underlying $\mathrm{Yb}$ body formation and other aspects in the piRNA pathway in ovarian somatic cells. Therefore, the establishment of cultured fly germ cells is eagerly awaited. Knockout of the lethal (3) malignant brain tumor [L(3)MBT], which encodes the transcriptional tumor repressor L(3)MBT, induced the ping-pong cycle in cultured OSCs. Many of the ping-pong factors, including Aub and Ago3, are not normally expressed in OSCs and the ping-pong cycle does not normally function in these cells [121]. Unlike original OSCs, OSC derivatives, termed $\triangle$ mbt-OSCs, assembled nuage. These OSC derivatives might greatly contribute to our understanding of the mechanism of nuage formation.

\section{Perspective}

In this review, we have discussed the piRNA pathway in the Drosophila ovary. We have particularly focused on the functions of intracellular structures and their components and on the regulatory mechanisms of molecular migration between the structures. However, the functions of components in the structures are not completely understood. Furthermore, there are questions that remain to be addressed. For instance, how are nuclear Dot COM and the nuage assembled in vivo, and which of 
the nucleases is/are responsible for the first cleavage of the primary piRNA precursors? In addition, analyses focusing on post-translational modifications and temporal regulation during oogenesis are anticipated to further our understanding of the piRNA pathway. Drosophila ovaries, supported by our accumulating understanding of the piRNA pathway, the vast array of Drosophila genetic tools, the availability of cultured OSCs, and emerging technologies like genome editing, will continue to bring us novel insights about piRNAs. At the same time, information about piRNAs in testis and in other animals, and studies concerning the crosstalk between the piRNA pathway and other pathways, will inform the researchers investigating the Drosophila ovarian piRNA pathway. These studies will collaboratively approach the fundamental question of how animals tackle transposons with piRNAs.

Funding: M.C.S. was funded by a Grant-in-Aid for Scientific Research from the Ministry of Education, Culture, Sports, Science and Technology (MEXT) of Japan (KAKENHI grant number 19H05466).

Acknowledgments: We are thankful to Kaoru Sato, Ryo Onishi, Kazuhiro Sakakibara, and the other members of the Siomi laboratories for discussions and comments on the manuscript.

Conflicts of Interest: The authors declare no conflict of interest.

\section{References}

1. Huang, X.; Fejes Tóth, K.; Aravin, A.A. piRNA biogenesis in Drosophila melanogaster. Trends Genet. 2017, 33, 882-894. [CrossRef] [PubMed]

2. Czech, B.; Munafò, M.; Ciabrelli, F.; Eastwood, E.L.; Fabry, M.H.; Kneuss, E.; Hannon, G.J. piRNA-guided genome defense: From biogenesis to silencing. Annu. Rev. Genet. 2018, 52, 131-157. [CrossRef] [PubMed]

3. Ozata, D.M.; Gainetdinov, I.; Zoch, A.; O'Carroll, D.; Zamore, P.D. PIWI-interacting RNAs: Small RNAs with big functions. Nat. Rev. Genet. 2019, 20, 89-108. [CrossRef] [PubMed]

4. Parhad, S.S.; Theurkauf, W.E. Rapid evolution and conserved function of the piRNA pathway. Open. Biol. 2019, 9, 180181. [CrossRef] [PubMed]

5. Ku, H.Y.; Lin, H. PIWI proteins and their interactors in piRNA biogenesis, germline development and gene expression. Natl. Sci. Rev. 2014, 1, 205-218. [CrossRef] [PubMed]

6. Rojas-Ríos, P.; Simonelig, M. piRNAs and PIWI proteins: Regulators of gene expression in development and stem cells. Development 2018, 145, dev161786. [CrossRef] [PubMed]

7. Yamashiro, H.; Siomi, M.C. PIWI-interacting RNA in Drosophila: Biogenesis, transposon regulation, and beyond. Chem. Rev. 2018, 118, 4404-4421. [CrossRef]

8. Hirakata, S.; Siomi, M.C. piRNA biogenesis in the germline: From transcription of piRNA genomic sources to piRNA maturation. Biochim. Biophys. Acta 2016, 1859, 82-92. [CrossRef]

9. Grimson, A.; Srivastava, M.; Fahey, B.; Woodcroft, B.J.; Chiang, H.R.; King, N.; Degnan, B.M.; Rokhsar, D.S.; Bartel, D.P. Early origins and evolution of microRNAs and Piwi-interacting RNAs in animals. Nature 2008, 455, 1193-1197. [CrossRef]

10. Bourque, G.; Burns, K.H.; Gehring, M.; Gorbunova, V.; Seluanov, A.; Hammell, M.; Imbeault, M.; Izsvák, Z.; Levin, H.L.; Macfarlan, T.S.; et al. Ten things you should know about transposable elements. Genome Biol. 2018, 19, 199. [CrossRef]

11. Yang, H.P.; Barbash, D.A. Abundant and species-specific DINE-1 transposable elements in 12 Drosophila genomes. Genome Biol. 2008, 9, R39. [CrossRef] [PubMed]

12. Brennecke, J.; Aravin, A.A.; Stark, A.; Dus, M.; Kellis, M.; Sachidanandam, R.; Hannon, G.J. Discrete small RNA-generating loci as master regulators of transposon activity in Drosophila. Cell 2007, 128, 1089-1103. [CrossRef] [PubMed]

13. Gunawardane, L.S.; Saito, K.; Nishida, K.M.; Miyoshi, K.; Kawamura, Y.; Nagami, T.; Siomi, H.; Siomi, M.C. A Slicer-mediated mechanism for repeat-associated siRNA 5' end formation in Drosophila. Science 2007, 315, 1587-1590. [CrossRef] [PubMed]

14. Cox, D.N.; Chao, A.; Lin, H. piwi encodes a nucleoplasmic factor whose activity modulates the number and division rate of germline stem cells. Development 2000, 127, 503-514.

15. Saito, K.; Nishida, K.M.; Mori, T.; Kawamura, Y.; Miyoshi, K.; Nagami, T.; Siomi, H.; Siomi, M.C. Specific association of Piwi with rasiRNAs derived from retrotransposon and heterochromatic regions in the Drosophila genome. Genes Dev. 2006, 20, 2214-2222. [CrossRef] 
16. Schüpbach, T.; Wieschaus, E. Female sterile mutations on the second chromosome of Drosophila melanogaster. II. Mutations blocking oogenesis or altering egg morphology. Genetics 1991, 129, 1119-1136.

17. Lin, H.; Spradling, A.C. A novel group of pumilio mutations affects the asymmetric division of germline stem cells in the Drosophila ovary. Development 1997, 124, 2463-2476.

18. Cox, D.N.; Chao, A.; Baker, J.; Chang, L.; Qiao, D.; Lin, H. A novel class of evolutionarily conserved genes defined by piwi are essential for stem cell self-renewal. Genes Dev. 1998, 12, 3715-3727. [CrossRef]

19. Schmidt, A.; Palumbo, G.; Bozzetti, M.P.; Tritto, P.; Pimpinelli, S.; Schäfer, U. Genetic and molecular characterization of sting, a gene involved in crystal formation and meiotic drive in the male germ line of Drosophila melanogaster. Genetics 1999, 151, 749-760.

20. Li, C.; Vagin, V.V.; Lee, S.; Xu, J.; Ma, S.; Xi, H.; Seitz, H.; Horwich, M.D.; Syrzycka, M.; Honda, B.M.; et al. Collapse of germline piRNAs in the absence of Argonaute3 reveals somatic piRNAs in flies. Cell 2009, 137, 509-521. [CrossRef]

21. Nishida, K.M.; Iwasaki, Y.W.; Murota, Y.; Nagao, A.; Mannen, T.; Kato, Y.; Siomi, H.; Siomi, M.C. Respective functions of two distinct Siwi complexes assembled during PIWI-interacting RNA biogenesis in Bombyx germ cells. Cell Rep. 2015, 10, 193-203. [CrossRef] [PubMed]

22. Carmell, M.A.; Girard, A.; van de Kant, H.J.G.; Bourc'his, D.; Bestor, T.H.; de Rooij, D.G.; Hannon, G.J. MIWI2 is essential for spermatogenesis and repression of transposons in the mouse male germline. Dev. Cell 2007, 12, 503-514. [CrossRef] [PubMed]

23. Deng, W.; Lin, H. miwi, a murine homolog of piwi, encodes a cytoplasmic protein essential for spermatogenesis. Dev. Cell 2002, 2, 819-830. [CrossRef]

24. Kuramochi-Miyagawa, S.; Kimura, T.; Ijiri, T.W.; Isobe, T.; Asada, N.; Fujita, Y.; Ikawa, M.; Iwai, N.; Okabe, M.; Deng, W.; et al. Mili, a mammalian member of piwi family gene, is essential for spermatogenesis. Development 2004, 131, 839-849. [CrossRef]

25. Saito, K.; Inagaki, S.; Mituyama, T.; Kawamura, Y.; Ono, Y.; Sakota, E.; Kotani, H.; Asai, K.; Siomi, H.; Siomi, M.C. A regulatory circuit for piwi by the large Maf gene traffic jam in Drosophila. Nature 2009, 461, 1296-1299. [CrossRef]

26. Niki, Y.; Yamaguchi, T.; Mahowald, A.P. Establishment of stable cell lines of Drosophila germ-line stem cells. Proc. Natl. Acad. Sci. USA 2006, 103, 16325-16330. [CrossRef]

27. McLaughlin, J.M.; Bratu, D.P. Drosophila melanogaster oogenesis: An overview. Methods Mol. Biol. 2015, 1328, 1-20.

28. Bastock, R.; St Johnston, D. Drosophila oogenesis. Curr. Biol. 2008, 18, R1082-R1087. [CrossRef]

29. Harris, A.N.; Macdonald, P.M. aubergine encodes a Drosophila polar granule component required for pole cell formation and related to eIF2C. Development 2001, 128, 2823-2832.

30. Rozhkov, N.V.; Hammell, M.; Hannon, G.J. Multiple roles for Piwi in silencing Drosophila transposons. Genes Dev. 2013, 27, 400-412. [CrossRef]

31. Sienski, G.; Dönertas, D.; Brennecke, J. Transcriptional silencing of transposons by Piwi and Maelstrom and its impact on chromatin state and gene expression. Cell 2012, 151, 964-980. [CrossRef] [PubMed]

32. Le Thomas, A.; Rogers, A.K.; Webster, A.; Marinov, G.K.; Liao, S.E.; Perkins, E.M.; Hur, J.K.; Aravin, A.A.; Fejes Tóth, K. Piwi induces piRNA-guided transcriptional silencing and establishment of a repressive chromatin state. Genes Dev. 2013, 27, 390-399. [CrossRef] [PubMed]

33. Wang, S.H.; Elgin, S.C. Drosophila Piwi functions downstream of piRNA production mediating a chromatin-based transposon silencing mechanism in female germ line. Proc. Natl. Acad. Sci. USA 2011, 108, 21164-21169. [CrossRef] [PubMed]

34. Klenov, M.S.; Sokolova, O.A.; Yakushev, E.Y.; Stolyarenko, A.D.; Mikhaleva, E.A.; Lavrov, S.A.; Gvozdev, V.A. Separation of stem cell maintenance and transposon silencing functions of Piwi protein. Proc. Natl. Acad. Sci. USA 2011, 108, 18760-18765. [CrossRef]

35. Klenov, M.S.; Lavrov, S.A.; Korbut, A.P.; Stolyarenko, A.D.; Yakushev, E.Y.; Reuter, M.; Pillai, R.S.; Gvozdev, V.A. Impact of nuclear Piwi elimination on chromatin state in Drosophila melanogaster ovaries. Nucleic Acids Res. 2014, 42, 6208-6218. [CrossRef]

36. Huang, X.A.; Yin, H.; Sweeney, S.; Raha, D.; Snyder, M.; Lin, H. A major epigenetic programming mechanism guided by piRNAs. Dev. Cell 2013, 24, 502-516. [CrossRef]

37. Sato, K.; Siomi, M.C. Two distinct transcriptional controls triggered by nuclear Piwi-piRISCs in the Drosophila piRNA pathway. Curr. Opin. Struct. Biol. 2018, 53, 69-76. [CrossRef] 
38. Batki, J.; Schnabl, J.; Wang, J.; Handler, D.; Andreev, V.I.; Stieger, C.E.; Novatchkova, M.; Lampersberger, L.; Kauneckaite, K.; Xie, W.; et al. The nascent RNA binding complex SFiNX licenses piRNA-guided heterochromatin formation. Nat. Struct. Mol. Biol. 2019, 26, 720-731. [CrossRef]

39. Zhao, K.; Cheng, S.; Miao, N.; Xu, P.; Lu, X.; Zhang, Y.; Wang, M.; Ouyang, X.; Yuan, X.; Liu, W.; et al. A Pandas complex adapted for piRNA-guided transcriptional silencing and heterochromatin formation. Nat. Cell Biol. 2019. [CrossRef]

40. Fabry, M.H.; Ciabrelli, F.; Munafò, M.; Eastwood, E.L.; Kneuss, E.; Falciatori, I.; Falconio, F.A.; Hannon, G.J.; Czech, B. piRNA-guided co-transcriptional silencing coopts nuclear export factors. Elife 2019, 8, e47999. [CrossRef] [PubMed]

41. Murano, K.; Iwasaki, Y.W.; Ishizu, H.; Mashiko, A.; Shibuya, A.; Kondo, S.; Adachi, S.; Suzuki, S.; Saito, K.; Natsume, T.; et al. Nuclear RNA export factor variant initiates piRNA-guided co-transcriptional silencing. EMBO J. 2019, 38, e102870. [CrossRef] [PubMed]

42. Iwasaki, Y.W.; Murano, K.; Ishizu, H.; Shibuya, A.; Iyoda, Y.; Siomi, M.C.; Siomi, H.; Saito, K. Piwi modulates chromatin accessibility by regulating multiple factors including histone $\mathrm{H} 1$ to repress transposons. Mol. Cell 2016, 63, 408-419. [CrossRef] [PubMed]

43. Sienski, G.; Batki, J.; Senti, K.A.; Dönertas, D.; Tirian, L.; Meixner, K.; Brennecke, J. Silencio/CG9754 connects the Piwi-piRNA complex to the cellular heterochromatin machinery. Genes Dev. 2015, 29, 2258-2271. [CrossRef] [PubMed]

44. Yu, Y.; Gu, J.; Jin, Y.; Luo, Y.; Preall, J.B.; Ma, J.; Czech, B.; Hannon, G.J. Panoramix enforces piRNA-dependent cotranscriptional silencing. Science 2015, 350, 339-342. [CrossRef]

45. Dönertas, D.; Sienski, G.; Brennecke, J. Drosophila Gtsf1 is an essential component of the Piwi-mediated transcriptional silencing complex. Genes Dev. 2013, 27, 1693-1705. [CrossRef]

46. Ohtani, H.; Iwasaki, Y.W.; Shibuya, A.; Siomi, H.; Siomi, M.C.; Saito, K. DmGTSF1 is necessary for Piwi-piRISC-mediated transcriptional transposon silencing in the Drosophila ovary. Genes Dev. 2013, 27, 1656-1661. [CrossRef]

47. Muerdter, F.; Guzzardo, P.M.; Gillis, J.; Luo, Y.; Yu, Y.; Chen, C.; Fekete, R.; Hannon, G.J. A genome-wide RNAi screen draws a genetic framework for transposon control and primary piRNA biogenesis in Drosophila. Mol. Cell 2013, 50, 736-748. [CrossRef]

48. Malone, C.D.; Brennecke, J.; Dus, M.; Stark, A.; McCombie, W.R.; Sachidanandam, R.; Hannon, G.J. Specialized piRNA pathways act in germline and somatic tissues of the Drosophila ovary. Cell 2009, 137, 522-535. [CrossRef]

49. Yamanaka, S.; Siomi, M.C.; Siomi, H. piRNA clusters and open chromatin structure. Mob. DNA 2014, 5, 22. [CrossRef]

50. Andersen, P.R.; Tirian, L.; Vunjak, M.; Brennecke, J. A heterochromatin-dependent transcription machinery drives piRNA expression. Nature 2017, 549, 54-59. [CrossRef]

51. Klattenhoff, C.; Xi, H.; Li, C.; Lee, S.; Xu, J.; Khurana, J.S.; Zhang, F.; Schultz, N.; Koppetsch, B.S.; Nowosielska, A.; et al. The Drosophila HP1 homolog Rhino is required for transposon silencing and piRNA production by dual-strand clusters. Cell 2009, 138, 1137-1149. [CrossRef] [PubMed]

52. Mohn, F.; Sienski, G.; Handler, D.; Brennecke, J. The Rhino-Deadlock-Cutoff complex licenses noncanonical transcription of dual-Strand piRNA clusters in Drosophila. Cell 2014, 157, 1364-1379. [CrossRef] [PubMed]

53. Zhang, Z.; Wang, J.; Schultz, N.; Zhang, F.; Parhad, S.S.; Tu, S.; Vreven, T.; Zamore, P.D.; Weng, Z.; Theurkauf, W.E. The HP1 homolog Rhino anchors a nuclear complex that suppresses piRNA precursor splicing. Cell 2014, 157, 1353-1363. [CrossRef] [PubMed]

54. Le Thomas, A.; Stuwe, E.; Li, S.; Du, J.; Marinov, G.; Rozhkov, N.; Chen, Y.C.; Luo, Y.; Sachidanandam, R.; Fejes Tóth, K.; et al. Transgenerationally inherited piRNAs trigger piRNA biogenesis by changing the chromatin of piRNA clusters and inducing precursor processing. Genes Dev. 2014, 28, 1667-1680. [CrossRef]

55. Pane, A.; Jiang, P.; Zhao, D.Y.; Singh, M.; Schüpbach, T. The Cutoff protein regulates piRNA cluster expression and piRNA production in the Drosophila germline. EMBO J. 2011, 30, 4601-4615. [CrossRef]

56. ElMaghraby, M.F.; Andersen, P.R.; Pühringer, F.; Hohmann, U.; Meixner, K.; Lendl, T.; Tirian, L.; Brennecke, J. A heterochromatin-specific RNA export pathway facilitates piRNA production. Cell 2019, 178, 964-979.e20. [CrossRef] 
57. Kneuss, E.; Munafò, M.; Eastwood, E.L.; Deumer, U.S.; Preall, J.B.; Hannon, G.J.; Czech, B. Specialization of the Drosophila nuclear export family protein Nxf3 for piRNA precursor export. Genes Dev. 2019, 33, 1208-1220. [CrossRef]

58. Robine, N.; Lau, N.C.; Balla, S.; Jin, Z.; Okamura, K.; Kuramochi-Miyagawa, S.; Blower, M.D.; Lai, E.C. A broadly conserved pathway generates 3'UTR-directed primary piRNAs. Curr. Biol. 2009, 19, 2066-2076. [CrossRef]

59. Iwasaki, Y.W.; Siomi, M.C.; Siomi, H. PIWI-interacting RNA: Its biogenesis and functions. Annu. Rev. Biochem. 2015, 84, 405-433. [CrossRef]

60. Szakmary, A.; Reedy, M.; Qi, H.; Lin, H. The Yb protein defines a novel organelle and regulates male germline stem cell self-renewal in Drosophila melanogaster. J. Cell Biol. 2009, 185, 613-627. [CrossRef]

61. Saito, K.; Ishizu, H.; Komai, M.; Kotani, H.; Kawamura, Y.; Nishida, K.M.; Siomi, H.; Siomi, M.C. Roles for the $\mathrm{Yb}$ body components Armitage and $\mathrm{Yb}$ in primary piRNA biogenesis in Drosophila. Genes Dev. 2010, 24, 2493-2498. [CrossRef] [PubMed]

62. Qi, H.; Watanabe, T.; Ku, H.Y.; Liu, N.; Zhong, M.; Lin, H. The Yb body, a major site for Piwi-associated RNA biogenesis and a gateway for Piwi expression and transport to the nucleus in somatic cells. J. Biol. Chem. 2011, 286, 3789-3797. [CrossRef] [PubMed]

63. Olivieri, D.; Sykora, M.M.; Sachidanandam, R.; Mechtler, K.; Brennecke, J. An in vivo RNAi assay identifies major genetic and cellular requirements for primary piRNA biogenesis in Drosophila. EMBO J. 2010, 29, 3301-3317. [CrossRef] [PubMed]

64. Handler, D.; Olivieri, D.; Novatchkova, M.; Gruber, F.S.; Meixner, K.; Mechtler, K.; Stark, A.; Sachidanandam, R.; Brennecke, J. A systematic analysis of Drosophila TUDOR domain-containing proteins identifies Vreteno and the Tdrd12 family as essential primary piRNA pathway factors. EMBO J. 2011, 30, 3977-3993. [CrossRef]

65. Olivieri, D.; Senti, K.A.; Subramanian, S.; Sachidanandam, R.; Brennecke, J. The cochaperone Shutdown defines a group of biogenesis factors essential for all piRNA populations in Drosophila. Mol. Cell 2012, 47, 954-969. [CrossRef]

66. Vagin, V.V.; Yu, Y.; Jankowska, A.; Luo, Y.; Wasik, K.A.; Malone, C.D.; Harrison, E.; Rosebrock, A.; Wakimoto, B.T.; Fagegaltier, D.; et al. Minotaur is critical for primary piRNA biogenesis. RNA 2013, 19, 1064-1077. [CrossRef]

67. Munafò, M.; Manelli, V.; Falconio, F.A.; Sawle, A.; Kneuss, E.; Eastwood, E.L.; Seah, J.W.E.; Czech, B.; Hannon, G.J. Daedalus and Gasz recruit Armitage to mitochondria, bringing piRNA precursors to the biogenesis machinery. Genes Dev. 2019, 33, 844-856. [CrossRef]

68. Handler, D.; Meixner, K.; Pizka, M.; Lauss, K.; Schmied, C.; Gruber, F.S.; Brennecke, J. The genetic makeup of the Drosophila piRNA pathway. Mol. Cell 2013, 50, 762-777. [CrossRef]

69. Pandey, R.R.; Homolka, D.; Chen, K.M.; Sachidanandam, R.; Fauvarque, M.O.; Pillai, R.S. Recruitment of Armitage and $\mathrm{Yb}$ to a transcript triggers its phased processing into primary piRNAs in Drosophila ovaries. PLoS Genet. 2017, 13, e1006956. [CrossRef]

70. Huang, H.; Li, Y.; Szulwach, K.E.; Zhang, G.; Jin, P.; Chen, D. AGO3 Slicer activity regulates mitochondria-nuage localization of Armitage and piRNA amplification. J. Cell Biol. 2014, 206, 217-230. [CrossRef]

71. Cook, H.A.; Koppetsch, B.S.; Wu, J.; Theurkauf, W.E. The Drosophila SDE3 homolog armitage is required for oskar mRNA silencing and embryonic axis specification. Cell 2004, 116, 817-829. [CrossRef]

72. Ge, D.T.; Wang, W.; Tipping, C.; Gainetdinov, I.; Weng, Z.; Zamore, P.D. The RNA-binding ATPase, Armitage, couples piRNA amplification in nuage to phased piRNA production on mitochondria. Mol. Cell 2019, 74, 982-995.e986. [CrossRef]

73. Zamparini, A.L.; Davis, M.Y.; Malone, C.D.; Vieira, E.; Zavadil, J.; Sachidanandam, R.; Hannon, G.J.; Lehmann, R. Vreteno, a gonad-specific protein, is essential for germline development and primary piRNA biogenesis in Drosophila. Development 2011, 138, 4039-4050. [CrossRef]

74. Mohn, F.; Handler, D.; Brennecke, J. piRNA-guided slicing specifies transcripts for Zucchini-dependent, phased piRNA biogenesis. Science 2015, 348, 812-817. [CrossRef]

75. Han, B.W.; Wang, W.; Li, C.; Weng, Z.; Zamore, P.D. piRNA-guided transposon cleavage initiates Zucchini-dependent, phased piRNA production. Science 2015, 348, 817-821. [CrossRef] 
76. Pane, A.; Wehr, K.; Schüpbach, T. zucchini and squash encode two putative nucleases required for rasiRNA production in the Drosophila germline. Dev. Cell 2007, 12, 851-862. [CrossRef]

77. Zhang, Z.; Xu, J.; Koppetsch, B.S.; Wang, J.; Tipping, C.; Ma, S.; Weng, Z.; Theurkauf, W.E.; Zamore, P.D. Heterotypic piRNA Ping-Pong requires Qin, a protein with both E3 ligase and Tudor domains. Mol. Cell 2011, 44, 572-584. [CrossRef]

78. Anand, A.; Kai, T. The tudor domain protein Kumo is required to assemble the nuage and to generate germline piRNAs in Drosophila. EMBO J. 2012, 31, 870-882. [CrossRef]

79. Lim, A.K.; Kai, T. Unique germ-line organelle, nuage, functions to repress selfish genetic elements in Drosophila melanogaster. Proc. Natl. Acad. Sci. USA 2007, 104, 6714-6719. [CrossRef]

80. Mahowald, A.P. Polar granules of Drosophila. 3. The continuity of polar granules during the life cycle of Drosophila. J. Exp. Zool. 1971, 176, 329-343. [CrossRef]

81. Mahowald, A.P. Assembly of the Drosophila germ plasm. Int. Rev. Cytol. 2001, 203, 187-213.

82. Dennis, C.; Zanni, V.; Brasset, E.; Eymery, A.; Zhang, L.; Mteirek, R.; Jensen, S.; Rong, Y.S.; Vaury, C. “Dot $\mathrm{COM}^{\prime \prime}$, a nuclear transit center for the primary piRNA pathway in Drosophila. PLoS ONE 2013, 8, e72752. [CrossRef]

83. Dennis, C.; Brasset, E.; Sarkar, A.; Vaury, C. Export of piRNA precursors by EJC triggers assembly of cytoplasmic Yb-body in Drosophila. Nat. Commun. 2016, 7, 13739. [CrossRef]

84. Sokolova, O.A.; Ilyin, A.A.; Poltavets, A.S.; Nenasheva, V.V.; Mikhaleva, E.A.; Shevelyov, Y.Y.; Klenov, M.S. $\mathrm{Yb}$ body assembly on the flamenco piRNA precursor transcripts reduces genic piRNA production. Mol. Biol. Cell 2019, 30, 1544-1554. [CrossRef]

85. Dennis, C.; Brasset, E.; Vaury, C. flam piRNA precursors channel from the nucleus to the cytoplasm in a temporally regulated manner along Drosophila oogenesis. Mob. DNA 2019, 10, 28. [CrossRef]

86. Murota, Y.; Ishizu, H.; Nakagawa, S.; Iwasaki, Y.W.; Shibata, S.; Kamatani, M.K.; Saito, K.; Okano, H.; Siomi, H.; Siomi, M.C. Yb integrates piRNA intermediates and processing factors into perinuclear bodies to enhance piRISC assembly. Cell Rep. 2014, 8, 103-113. [CrossRef]

87. Lau, N.C.; Robine, N.; Martin, R.; Chung, W.J.; Niki, Y.; Berezikov, E.; Lai, E.C. Abundant primary piRNAs, endo-siRNAs, and microRNAs in a Drosophila ovary cell line. Genome Res. 2009, 19, 1776-1785. [CrossRef]

88. Desset, S.; Meignin, C.; Dastugue, B.; Vaury, C. COM, a heterochromatic locus governing the control of independent endogenous retroviruses from Drosophila melanogaster. Genetics 2003, 164, 501-509.

89. Pélisson, A.; Song, S.U.; Prud'homme, N.; Smith, P.A.; Bucheton, A.; Corces, V.G. Gypsy transposition correlates with the production of a retroviral envelope-like protein under the tissue-specific control of the Drosophila flamenco gene. EMBO J. 1994, 13, 4401-4411. [CrossRef]

90. Prud'homme, N.; Gans, M.; Masson, M.; Terzian, C.; Bucheton, A. Flamenco, a gene controlling the gypsy retrovirus of Drosophila melanogaster. Genetics 1995, 139, 697-711.

91. Goriaux, C.; Desset, S.; Renaud, Y.; Vaury, C.; Brasset, E. Transcriptional properties and splicing of the flamenco piRNA cluster. EMBO Rep. 2014, 15, 411-418. [CrossRef]

92. Hirakata, S.; Ishizu, H.; Fujita, A.; Tomoe, Y.; Siomi, M.C. Requirements for multivalent Yb body assembly in transposon silencing in Drosophila. EMBO Rep. 2019, 20, e47708. [CrossRef]

93. Ishizu, H.; Iwasaki, Y.W.; Hirakata, S.; Ozaki, H.; Iwasaki, W.; Siomi, H.; Siomi, M.C. Somatic primary piRNA biogenesis driven by cis-acting RNA elements and trans-acting Yb. Cell Rep. 2015, 12, 429-440. [CrossRef]

94. Ishizu, H.; Kinoshita, T.; Hirakata, S.; Komatsuzaki, C.; Siomi, M.C. Distinct and collaborative functions of $\mathrm{Yb}$ and Armitage in transposon-targeting piRNA biogenesis. Cell Rep. 2019, 27, 1822-1835.e8. [CrossRef]

95. Rogers, A.K.; Situ, K.; Perkins, E.M.; Fejes Tóth, K. Zucchini-dependent piRNA processing is triggered by recruitment to the cytoplasmic processing machinery. Genes Dev. 2017, 31, 1858-1869. [CrossRef]

96. Yamashiro, H.; Negishi, M.; Kinoshita, T.; Ishizu, H.; Ohtani, H.; Siomi, M.C. Armitage determines Piwi-piRISC processing from precursor formation and quality control to inter-organelle translocation. EMBO Rep. 2019. under review.

97. Nishimasu, H.; Ishizu, H.; Saito, K.; Fukuhara, S.; Kamatani, M.K.; Bonnefond, L.; Matsumoto, N.; Nishizawa, T.; Nakanaga, K.; Aoki, J.; et al. Structure and function of Zucchini endoribonuclease in piRNA biogenesis. Nature 2012, 491, 284-287. [CrossRef]

98. Voigt, F.; Reuter, M.; Kasaruho, A.; Schulz, E.C.; Pillai, R.S.; Barabas, O. Crystal structure of the primary piRNA biogenesis factor Zucchini reveals similarity to the bacterial PLD endonuclease Nuc. RNA 2012, 18, 2128-2134. [CrossRef] 
99. Feltzin, V.L.; Khaladkar, M.; Abe, M.; Parisi, M.; Hendriks, G.J.; Kim, J.; Bonini, N.M. The exonuclease Nibbler regulates age-associated traits and modulates piRNA length in Drosophila. Aging Cell 2015, 14, 443-452. [CrossRef]

100. Wang, H.; Ma, Z.; Niu, K.; Xiao, Y.; Wu, X.; Pan, C.; Zhao, Y.; Wang, K.; Zhang, Y.; Liu, N. Antagonistic roles of Nibbler and Hen1 in modulating piRNA $3^{\prime}$ ends in Drosophila. Development 2016, 143, 530-539. [CrossRef]

101. Hayashi, R.; Schnabl, J.; Handler, D.; Mohn, F.; Ameres, S.L.; Brennecke, J. Genetic and mechanistic diversity of piRNA $3^{\prime}$-end formation. Nature 2016, 539, 588-592. [CrossRef] [PubMed]

102. Horwich, M.D.; Li, C.; Matranga, C.; Vagin, V.; Farley, G.; Wang, P.; Zamore, P.D. The Drosophila RNA methyltransferase, DmHen1, modifies germline piRNAs and single-stranded siRNAs in RISC. Curr. Biol. 2007, 17, 1265-1272. [CrossRef] [PubMed]

103. Saito, K.; Sakaguchi, Y.; Suzuki, T.; Siomi, H.; Siomi, M.C. Pimet, the Drosophila homolog of HEN1, mediates 2'-O-methylation of Piwi-interacting RNAs at their 3' ends. Genes Dev. 2007, 21, 1603-1608. [CrossRef]

104. Homolka, D.; Pandey, R.R.; Goriaux, C.; Brasset, E.; Vaury, C.; Sachidanandam, R.; Fauvarque, M.O.; Pillai, R.S. PIWI slicing and RNA elements in precursors instruct directional primary piRNA biogenesis. Cell Rep. 2015, 12, 418-428. [CrossRef] [PubMed]

105. Wang, W.; Han, B.W.; Tipping, C.; Ge, D.T.; Zhang, Z.; Weng, Z.; Zamore, P.D. Slicing and binding by Ago3 or Aub trigger Piwi-bound piRNA production by distinct mechanisms. Mol. Cell 2015, 59, 819-830. [CrossRef]

106. Yashiro, R.; Murota, Y.; Nishida, K.M.; Yamashiro, H.; Fujii, K.; Ogai, A.; Yamanaka, S.; Negishi, L.; Siomi, H.; Siomi, M.C. Piwi nuclear localization and its regulatory mechanism in Drosophila ovarian somatic cells. Cell Rep. 2018, 23, 3647-3657. [CrossRef]

107. Preall, J.B.; Czech, B.; Guzzardo, P.M.; Muerdter, F.; Hannon, G.J. shutdown is a component of the Drosophila piRNA biogenesis machinery. RNA 2012, 18, 1446-1457. [CrossRef]

108. Webster, A.; Li, S.; Hur, J.K.; Wachsmuth, M.; Bois, J.S.; Perkins, E.M.; Patel, D.J.; Aravin, A.A. Aub and Ago3 are recruited to nuage through two mechanisms to form a ping-pong complex assembled by Krimper. Mol. Cell 2015, 59, 564-575. [CrossRef]

109. Kibanov, M.V.; Egorova, K.S.; Ryazansky, S.S.; Sokolova, O.A.; Kotov, A.A.; Olenkina, O.M.; Stolyarenko, A.D.; Gvozdev, V.A.; Olenina, L.V. A novel organelle, the piNG-body, in the nuage of Drosophila male germ cells is associated with piRNA-mediated gene silencing. Mol. Biol. Cell 2011, 22, 3410-3419. [CrossRef]

110. Aravin, A.A.; van der Heijden, G.W.; Castañeda, J.; Vagin, V.V.; Hannon, G.J.; Bortvin, A. Cytoplasmic compartmentalization of the fetal piRNA pathway in mice. PLoS Genet. 2009, 5, e1000764. [CrossRef]

111. Liang, L.; Diehl-Jones, W.; Lasko, P. Localization of vasa protein to the Drosophila pole plasm is independent of its RNA-binding and helicase activities. Development 1994, 120, 1201-1211. [PubMed]

112. Xiol, J.; Spinelli, P.; Laussmann, M.A.; Homolka, D.; Yang, Z.; Cora, E.; Couté, Y.; Conn, S.; Kadlec, J.; Sachidanandam, R.; et al. RNA clamping by Vasa assembles a piRNA amplifier complex on transposon transcripts. Cell 2014, 157, 1698-1711. [CrossRef] [PubMed]

113. Nott, T.J.; Petsalaki, E.; Farber, P.; Jervis, D.; Fussner, E.; Plochowietz, A.; Craggs, T.D.; Bazett-Jones, D.P.; Pawson, T.; Forman-Kay, J.D.; et al. Phase transition of a disordered nuage protein generates environmentally responsive membraneless organelles. Mol. Cell 2015, 57, 936-947. [CrossRef] [PubMed]

114. Patil, V.S.; Kai, T. Repression of retroelements in Drosophila germline via piRNA pathway by the tudor domain protein Tejas. Curr. Biol. 2010, 20, 724-730. [CrossRef]

115. Findley, S.D.; Tamanaha, M.; Clegg, N.J.; Ruohola-Baker, H. Maelstrom, a Drosophila spindle-class gene, encodes a protein that colocalizes with Vasa and RDE1/AGO1 homolog, Aubergine, in nuage. Development 2003, 130, 859-871. [CrossRef]

116. Zhang, F.; Wang, J.; Xu, J.; Zhang, Z.; Koppetsch, B.S.; Schultz, N.; Vreven, T.; Meignin, C.; Davis, I.; Zamore, P.D.; et al. UAP56 couples piRNA clusters to the perinuclear transposon silencing machinery. Cell 2012, 151, 871-884. [CrossRef]

117. Barbosa, V.; Kimm, N.; Lehmann, R. A maternal screen for genes regulating Drosophila oocyte polarity uncovers new steps in meiotic progression. Genetics 2007, 176, 1967-1977. [CrossRef]

118. Sato, K.; Iwasaki, Y.W.; Shibuya, A.; Carninci, P.; Tsuchizawa, Y.; Ishizu, H.; Siomi, M.C.; Siomi, H. Krimper enforces an antisense bias on piRNA pools by binding AGO3 in the Drosophila germline. Mol. Cell 2015, 59, 553-563. [CrossRef]

119. Nagao, A.; Sato, K.; Nishida, K.M.; Siomi, H.; Siomi, M.C. Gender-specific hierarchy in nuage localization of PIWI-interacting RNA factors in Drosophila. Front. Genet. 2011, 2, 55. [CrossRef] 
120. Zhang, Z.; Koppetsch, B.S.; Wang, J.; Tipping, C.; Weng, Z.; Theurkauf, W.E.; Zamore, P.D. Antisense piRNA amplification, but not piRNA production or nuage assembly, requires the Tudor-domain protein Qin. EMBOJ. 2014, 33, 536-539. [CrossRef]

121. Sumiyoshi, T.; Sato, K.; Yamamoto, H.; Iwasaki, Y.W.; Siomi, H.; Siomi, M.C. Loss of l(3)mbt leads to acquisition of the ping-pong cycle in Drosophila ovarian somatic cells. Genes Dev. 2016, 30, 1617-1622. [CrossRef] [PubMed]

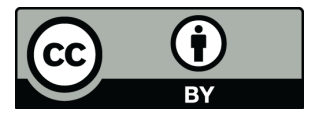

(C) 2019 by the authors. Licensee MDPI, Basel, Switzerland. This article is an open access article distributed under the terms and conditions of the Creative Commons Attribution (CC BY) license (http://creativecommons.org/licenses/by/4.0/). 